\title{
The Resilience of Micro, Small and Medium Enterprises towards Economic Turbulansi: Is Entrepreneur Orientation a Determinant? (Literature Review Based on Intelligent Software)
}

\author{
Siska Maya ${ }^{1}$, Noermijati $^{2}$, Rofiaty $^{3}$, Ainur Rofiq $^{4}$ \\ \{*may3110@yahoo.com\} \\ ${ }^{12,3,4}$ Management Departement, Faculty of Economic and Business, [Universitas Brawijaya]
}

\begin{abstract}
Entrepreneurship is now important in running the micro small and medium business world. The purpose of this study is to clarify the concept of Entrepreneur Orientation (EO); Are there other variables besides entrepreneurs in determining business continiuty; and Explore the trends in the entrepreneurial orientation and suggest a future research topic. In the business world indicators that are often used in entrepreneur orientation are innovative, risk-making and proactive. This research method uses literature from scientific articles, data is collected and analyzed using Publish or Perish (PoP) and vosviewers software. The implications of this research will certainly be useful for business people to keep their organizations running and also for researchers by knowing future research opportunities about entrepreneur orientation.
\end{abstract}

Keyword : Entrepreneur, Orientation.

\section{Introduction}

Many factors determine whether or not a micro small and medium business will survive. Various aspects are used in creating a sustainable business. Businesses that continue to run continuously will certainly affect a country's economic conditions. From the existing literature from various countries, smaller scale, little and medium ventures have a significant contribution to economic growth. Conducted a survey of 12,000 companies in 27 creating nations that small and medium businesses have a contribution to a country's economy [1]. Some research determines the determinants of the maintainability of micro small and medium businesses even though the economic condition is not good. Small and medium businesses have an important role in economic development [2]. Two variables that are highlighted in this article are entrepreneur orientation and customer orientation. Entrepreneur orientation was first investigated [3] who discussed personal orientation inventory with entrepreneur orientation. In recent years there have been numerous examinatios linking entrepreneur orientation with other variables. Makes entrepreneurial orientation a mediating variable between variables of capability, creativity and innovation on company performance [4]. This study aims to clarify the concept of Entrepreneur Orientation (EO); Are there other variables besides entrepreneurs in determining business continiuty; and Explore the trends in the entrepreneurial orientation and suggest a future research topic.

Entrepreneur Orientation Research develops from year to year. There are three dimensions 
in the EO variable (entrepreneurial orientation), namely innovation, risk taking and proactivity [5],[6],[7],[8],[9],[10],[11], [12], [13], [14],[15]. Entrepreneurial oriented behavior is the driving force for product innovation success when it has the power of market oriented behavior [16]. Entrepreneur Orientation has a significant relationship to the performance of Micro, Small and Medium Enterprises withmediation market oriented [17].

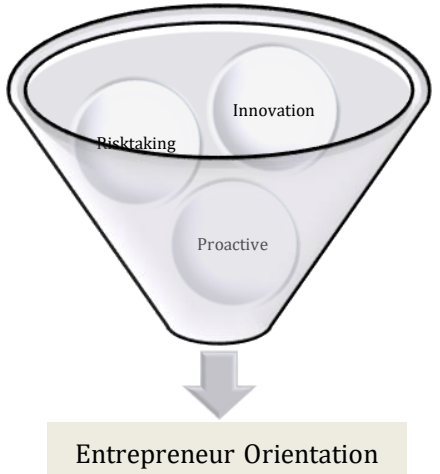

Fig.1. Indicators used in the entrepreneurial orientation

The behavior entrepreneurial orientation resulted in better small and medium business growth [18]; [19]; [20];. [21], which is part of a proactive entrepreneur orientation is important in influencing the performance business. The exhibition of a business will be good if goals are achieved management, which are effective and efficient. There is an influence positive between entrepreneur orientation and the effectiveness of a company [22].

\section{Methods}

Maps and analyzes the results of scientific work related to entrepreneur orientation using bibliometric analysis. Bibliometric studies are carried out to broaden the scale of knowledge in this field and which will contribute to future research. Data collected from the Google Researcher database in June 2020 using Publish or Perish (PoP) and vosviewers software. First search by entering the word entrepreneuruer orientation. We limit the year to 5 years, 2015-2020. Limitation on the number of articles is done because the maximum article that can be accommodated by software is only 1000 articles. The number of initial searches for articles related to entrepreneur orientation was 985 . Articles were 985 reduced to 408 by selecting articles with criteria for journals, using English, not zero cites, and articles published in journals Q1 and Q2. (Table 2).

Table 1. Database searching

\begin{tabular}{ll}
\hline Initial Entreprenieur Orientation & 985 \\
No Article/Book Review/prosiding & 240 \\
no english & 103 \\
zeo cites & 116 \\
Q1/Q2 & 118 \\
Final Result & $\mathbf{4 0 8}$ \\
\hline
\end{tabular}


Table 1. Differences in The Search Process (Entrepreneur orientation)

\begin{tabular}{|l|c|c|}
\hline & keyword & Refinement \\
\hline Paper & 985 & 408 \\
\hline Citation & 22551 & 11187 \\
\hline Year & 5 & 5 \\
\hline Cites_Year & 4510.20 & 2237.40 \\
\hline Cites_Paper & 22.89 & 27.42 \\
\hline Cites_Author & 2,41 & 2.74 \\
\hline h_index & 61 & 52 \\
\hline Year_First & 2015 & 2015 \\
\hline Year_last & 2020 & 2020 \\
\hline
\end{tabular}

\section{Result and Discussion}

Research that discusses entrepreneur orientation from 2015 to June 2020 there were 985 articles. This research is spread in various publications such as Elsiver, Emerald and others. In the picture seen in 2017 exploration identified with innovation direction upwards of 214 articles. The 2018 study discussed the lowest entrepreneurial orientation discussed during 2015-2020. 2020 is still in development because the articles were collected until June 2020. 2020 still has the potential for the development of articles that discuss entrepreneurial orientation.

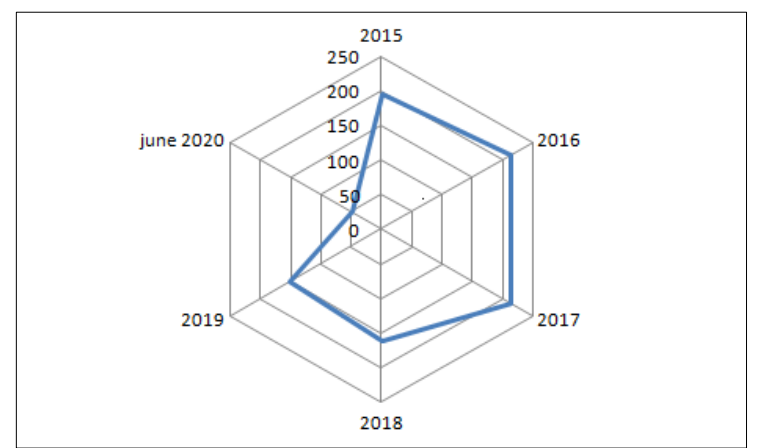

Fig.2. Entrepreneurial orientation article development

The number of 985 articles underwent a process by not including articles that were not journals, not speaking english, articles that were not cited, and separating articles that were included in journals Q1 and Q2. (Table.2). PoP software helps in separating articles. Articles 
included in the Q1 journal have a 31\% reputation in the International Entrepreneurship and Management Journal. 69\% of other articles are published in the Journal of Business Ethics, Journal of Business Venturing, International Business Review, European Management Journal and others. While Q2 discusses about entrepreneurial orientation 35\% in the International Journal of Emerging Markets, 22\% in Entrepreneurial Business and Economics Review and $43 \%$ in several journals such as Journal of Brand Management, Global Business Review and others.

\begin{tabular}{ccc} 
& Table 3. Journal Publication \\
\hline Quartil Amount & \multicolumn{1}{c}{ Name of Journal } \\
\hline Q1 & International Entrepreneurship and Management Journal (25), Journal of \\
& Business Ethics (8), Journal of Business Venturing (7), International \\
& Business Review (4), European Management Journal (4), Academy of \\
& Management Perspectives (1), Annals of Operations Research (1), Annals \\
& of Tourism Research (2), Appetite (1), BRQ Business Research Quarterly \\
& (1), Burnout Research (1), Business Strategy and the Environment (1), \\
& Corporate Social Responsibility and Enviromental Management (1), \\
& Creativity and Innovation Management (1), European Business Review (1), \\
& Family Business Review (1), Industrial Marketing Management (7), \\
& Industry and Innovation (2), International Small Business Journal (2), \\
& Current Issues in Tourism (1), Ethnic and Racial Studies(1), Journal of \\
& Balkan and Near Eastern Studies (1), Journal of Chinese Economic and \\
& Business Studies (1), Journal of cleaner production (4), Journal of \\
& Consumer Research (1), Technological Forecasting and Social Change (1). \\
& International Journal of Emerging Markets (13), Entrepreneurial Business \\
& and Economics Review (8), Journal of Brand Management (3), Global \\
& Business Review (2), African Journal of Economic and Management \\
& Studies (1), Asia Pacific Journal of Marketing and Logistics (1), Asia \\
& Pacific Management Review (1), Baltic Journal of Management (1), \\
& Chinese Management Studies (1), Current Psychology (1), Social \\
& Enterprise Journal (1), Economic research-Ekonomska (1), Accounting and \\
& Business Research (1), International Journal of Consumer (1), Accounting \\
& and Business Research (1). \\
&
\end{tabular}

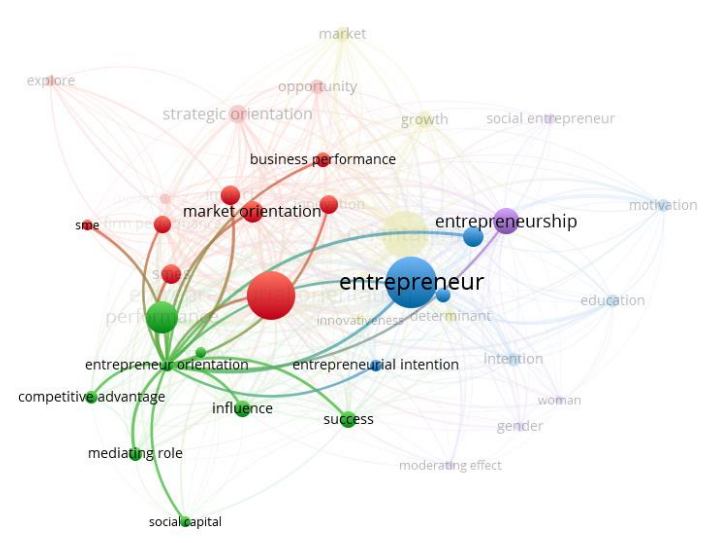

Fig.3. Network Visualization results of VOSviewer 
Entrepreneur orientation are usually discussed in research together with business performance, market orientation, competitive advantage. In figure 3, there is not much entrepreneur orientation research related to innovation, growth, strategic orientation. Entrepreneur orientation research has a lot to do with competitive advantage, mediation roles and social capital. This study consisted of five clusters consisting of 37 items.

\section{Conclusion}

Entrepreneur Orientation becomes a determining factor in running a business. Entrepreneur Orientation is research that can still be developed again. Explration identified with pioneering direction is closely related to three indicators, namely innovation, risktaking and proactive. This research is interesting to be examined from the development of indicators used to link religious observance. In the future, there is still a lot of research that needs to be explored, in particular the connection between entrepreneurial orientation and innovativeness, growth, and strategic orientation.

\section{Reference}

[1] A. Islam, "Economic growth and crime against small and medium sized enterprises in developing economies," Small Bus. Econ., 2014.

[2] C. A. Ahmed and M. H. Ali, "Growth of Small and Medium Enterprises in Sindh : Role of Socio Economic, Cultural and Political factors," pp. 155-172.

[3] M. Lessner and R. Knapp, R, "ORIENTATION AMONG SMALL BUSINESS OWNERS :," Educ. Psychol. Meas., vol. 34, pp. 455-460, 1974.

[4] J. Ferreira, A. Coelho, and L. Moutinho, "Technovation Dynamic capabilities , creativity and innovation capability and their impact on competitive advantage and fi $\mathrm{rm}$ performance: The moderating role of entrepreneurial orientation," Technovation, no. July, pp. 0-1, 2018.

[5] D. Miller, "The Correlates of Entrepreneurship in Three Types of Firms," no. May 2014, 1983.

[6] H. Barrett and A. Weinstein, "The Effect of Market Orientation and Organizational Flexibility on Corporate Entrepreneurship,” Business, Manag. Econ. Jounal, pp. 57-70, 1998.

[7] B. H. Kemelgor and B. H. Kemelgor, "A comparative analysis of corporate entrepreneurial orientation between selected firms in the Netherlands and the USA A comparative analysis of corporate entrepreneurial and the USA," Entrep. Reg. Dev., vol. 14, no. 1, pp. 67-87, 2002.

[8] L. Marino, K. Strandholm, H. K. Steensma, and K. M. Weaver, "The Moderating Effect of National Culture on the Relationship between Entrepreneurial Orientation and Strategic Alliance Portfolio Extensiveness," Sage J. Entrep. Theory Pract., pp. 145-160, 2002.

[9] P. Dimitratos, S. Lioukas, and S. Carter, "The relationship between entrepreneurship and international performance : the importance of domestic environment," Int. Bus. Rev., vol. 13, pp. 19-41, 2004.

[10] O. C. Richard, T. Barnett, S. Dwyer, and K. Chadwick, "CULTURAL DIVERSITY IN MANAGEMENT , FIRM PERFORMANCE , AND THE MODERATING ROLE OF ENTREPRENEURIAL ORIENTATION DIMENSIONS," Acad. Manag. J., vol. 47, no. 2, pp. 255-266, 2004.

[11] J. Wiklund and D. Shepherd, "Entrepreneurial orientation and small business performance : a configurational approach," J. Bus. Ventur., vol. 20, pp. 71-91, 2005.

[12] A. R. I. Jantunen, "Entrepreneurial Orientation , Dynamic Capabilities and International Performance," J. Int. Entrep., vol. 3, pp. 223-243, 2005.

[13] W. Stam and T. Elfring, "ENTREPRENEURIAL ORIENTATION AND NEW VENTURE 
PERFORMANCE: THE MEDIATING EFFECT OF NETWORK STRATEGIES,”Acad. Manag. Best Conf. Pap., vol. 1, pp. 162-163, 2006.

[14] G. R. Javalgi and P. R. Todd, "Entrepreneurial orientation , management commitment , and human capital : The internationalization of SMEs in India," J. Bus. Res., vol. 64, no. 9, pp. 1004 1010, 2011.

[15] M. Abebe, "Electronic commerce adoption, entrepreneurial orientation and small- and mediumsized enterprise ( SME ) performance,” J. Small Bus. Enterp. Dev., vol. 21, no. 1, pp. 100-116, 2014.

[16] N. Boso, J. W. Cadogan, and V. M. Story, "Complementary effect of entrepreneurial and market orientations on export new product success under differing levels of competitive intensity and financial capital," Int. Bus. Rev., vol. 21, no. 4, pp. 667-681, 2012.

[17] M. Amin, R. Thurasamy, A. . Aldakhil, and A. Hafeez Bin Kaswuri, "Nankai Business Review International," Nankai Bus. Rev. Int. J., vol. 7, no. 1, pp. 1-22, 2016.

[18] S. M. Lee and Æ. S. Lim, "Entrepreneurial orientation and the performance of service business," Serv. Bus., vol. 3, no. 1, pp. 1-13, 2009.

[19] J. Soininen, M. Martikainen, K. Puumalainen, and K. Kyl, "Int . J . Production Economics Entrepreneurial orientation: Growth and profitability of Finnish," Int. J. Prod. Econ., vol. 140, pp. 614-621, 2012.

[20] J. A. Wolff, T. L. Pett, and J. K. Ring, "Small firm growth as a function of both learning orientation and entrepreneurial orientation An empirical analysis James," Int. J. Entrep. Behav. Res., vol. 21, no. 5, pp. 709-730, 2015.

[21] G. J. Avlonitis and H. E. Salavou, "Entrepreneurial orientation of SMEs, product innovativeness

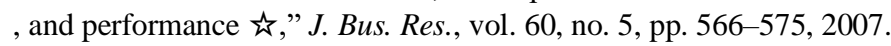

[22] K. Tajeddini, U. Elg, and M. Trueman, "Journal of Retailing and Consumer Services Ef fi ciency and effectiveness of small retailers: The role of customer and entrepreneurial orientation," $J$. Retail. Consum. Serv., vol. 20, no. 5, pp. 453-462, 2013. 
